\title{
THE STIMULATION OF MOUSE OVARIAN FOLLICULAR GROWTH IN VITRO BY DIBUTYRYL CYCLIC ADENOSINE $3^{\prime}: 5^{\prime}$ MONOPHOSPHATE
}

\author{
MARGARET RYLE \\ Birmingham and Midland Hospital for Women, \\ Showell Green Lane, Birmingham B11 $4 H L$
}

(Received 30th April 1974)

Both FSH and LH stimulate ovarian follicular growth during prolonged incubation in vitro, the response to FSH being detectable after 1 day whereas that to LH first appears after 3 days (Ryle, 1971a, b). Both hormones also enhance the synthesis of cyclic adenosine $3^{\prime}: 5^{\prime}$ monophosphate (cyclic AMP) by ovarian tissue during brief periods of incubation (Fontaine, Fontaine-Bertrand, Delerue-Labelle \& Salmon, 1971; Koch, Zor, Pomerantz, Chobsiang \& Lindner, 1973; Mason, Schaffer \& Toomey, 1973). Most studies on the effects of cyclic AMP on endocrine target tissues have involved only short exposures and rapid responses. Both rabbit and rat Graafian follicles, however, undergo luteinization following treatment with either LH or cyclic AMP (Miller \& Keyes, 1972; Ellsworth \& Armstrong, 1973) and adrenal cortical cells of the fetal rat exposed to cyclic AMP for several days eventually undergo changes similar to those induced by ACTH (Milner, 1972). It was therefore of interest to see whether cyclic AMP, or its more stable dibutyric derivative, could induce long-term effects on ovarian growth similar to those of either FSH or LH.

The source of tissue and the general culture conditions were as described previously (Ryle, 1971b, as modified by Boggis \& Ryle, 1972). In each experiment, the intact ovaries from a single foster litter of 15-day-old mice were distributed at random to the various culture dishes, where they were supported on stainless steel grids covered with strips of 'Velin' tissue (General Paper \& Box Company, Treforest, Glamorgan). Serum from an hypophysectomized sheep $(5 \%$ ) was added to the medium in Exp. 1, but was not available for Exp. 2 in which normal calf serum was used. The gas phase (air) was at atmospheric pressure in Exp. 1 but was increased by $0.2 \mathrm{~kg} / \mathrm{cm}^{2}$ in Exp. 2 to minimize tissue damage.

In Exp. 1, the effects of $\mathrm{N}^{6}-2: 0$-dibutyryl cyclic AMP (dcAMP; C. F. Boehring \& Son, Mannheim) on ovarian uptake of $\left[\mathrm{Me}-{ }^{3} \mathrm{H}\right]$ thymidine was studied, as earlier work showed that this was closely related to follicular growth (Ryle, 1971b, 1972; Kent, 1973). Eight of the sixteen culture dishes received $50 \mu \mathrm{mol}$ dcAMP daily in $0.01 \mathrm{ml}$ medium. Amounts of $\left[{ }^{3} \mathrm{H}\right]$ thymidine $(0.4 \mu \mathrm{Ci} /$ dish) were added to four experimental and four control dishes 1 day after the cultures were explanted. Two days later, the ovaries from these dishes were 
prepared for counting as described previously (Ryle, 1971b) and $\left[{ }^{3} \mathrm{H}\right]$ thymidine was added to the remaining dishes. The ovaries from the latter were prepared for counting after a further 3 days' culture. The mean tritium counts of experimental and control ovaries were compared for each culture period using Student's $t$ test. During Days 2 and 3 of culture, the mean uptake was $1515 \pm 91$ counts/ $0 \cdot 1 \mathrm{~min} /$ ovary when dcAMP had been added to the medium, compared to $1085 \pm 36$ in the control cultures. The corresponding figures for Days 4 to 6 were $2144 \pm 317$ and $542 \pm 58$. Both differences were significant at the $1 \%$ level.

Table 1. Follicle numbers and the proportion of follicles with mitotic figures in the granulosa cell layer of mouse ovaries cultured for 3 or 5 days in the presence or absence of dibutyryl cyclic AMP

\begin{tabular}{|c|c|c|c|c|c|c|c|}
\hline & & \multicolumn{4}{|c|}{$\begin{array}{l}\text { Follicles with three } \\
\text { layers of } \\
\text { granulosa cells }\end{array}$} & \multirow{2}{*}{\multicolumn{2}{|c|}{$\begin{array}{c}\begin{array}{c}\text { Follicles with four } \\
\text { layers of } \\
\text { granulosa cells }\end{array} \\
\text { Mean no./ovary }\end{array}$}} \\
\hline & & \multicolumn{2}{|c|}{ Mean no./ovary } & \multicolumn{2}{|c|}{$\begin{array}{l}\text { Mean } \% \text { with } \\
\text { mitotic figures }\end{array}$} & & \\
\hline & & Day 3 & Day 5 & Day 3 & Day 5 & Day 3 & Day 5 \\
\hline $\begin{array}{l}\text { Without dcAMP } \\
\text { With dcAMP }\end{array}$ & & $\begin{array}{l}12 \cdot 50 \\
18 \cdot 50\end{array}$ & $\left.\begin{array}{l}13.75 \\
23.75\end{array}\right\} *$ & $\left.\begin{array}{l}17 \cdot 5 \\
60.0\end{array}\right\}$ & * $\begin{array}{l}87.4 \\
86.9\end{array}$ & $\begin{array}{l}3 \cdot 25 \\
4 \cdot 00\end{array}$ & $\begin{array}{l}15 \cdot 25 \\
13 \cdot 50\end{array}$ \\
\hline $\begin{array}{l}\text { Source of variance } \\
\text { dcAMP } \\
\text { Time } \\
\text { Interaction } \\
\text { Residual }\end{array}$ & $\begin{array}{c}d . f . \\
1 \\
1 \\
1 \\
11\end{array}$ & $\begin{array}{c}M . S . \\
256 \\
42 \\
16 \\
31\end{array}$ & $\begin{array}{c}\text { P } \\
<0.05 \\
\text { N.S. } \\
\text { N.S. }\end{array}$ & $\begin{array}{r}M . S . \\
1760 \\
9370 \\
1849 \\
287\end{array}$ & $\begin{array}{c}P \\
<0.05 \\
<0.001 \\
<0.05\end{array}$ & $\begin{array}{c}M . S . \\
1 \\
462 \\
7 \\
8\end{array}$ & $\begin{array}{c}\text { P } \\
\text { N.S. } \\
<0.001 \\
\text { N.S. }\end{array}$ \\
\hline
\end{tabular}

In Exp. 2, the effect of dcAMP on follicular growth was investigated morphologically. The ovaries were cultured for 3 or 5 days in medium with or without $50 \mu \mathrm{mol}$ dcAMP. To avoid any possible effects due either to toxic breakdown products of dcAMP or to steroid which might accumulate as a result of dcAMP stimulation, all ovaries were transferred daily to fresh medium. After 3 days' culture, $2 \mu \mathrm{g}$ Colcemid (Sigma, London) were added to four experimental and four control dishes to arrest cells undergoing mitosis, and $4 \mathrm{hr}$ later these ovaries were fixed in Bouin's aqueous fixative. The remaining ovaries (four experimental and four control) were treated with Colcemid and fixed after 5 days' culture. Each ovary was serially sectioned and code numbers were allotted to the slides. Within each ovary, those follicles which had three layers and those which had four or more layers of granulosa cells were counted, each follicle being examined in that section which included the oocyte nucleolus. The presence or absence of mitotic figures in their granulosa cells was also recorded. Analyses of variance were carried out for the parameters studied. Some sections were lost from one ovary. The mean value for the remaining three in that treatment group was inserted for each parameter and the residual degrees of freedom were reduced by one. The results are shown in Table 1. Dibutyryl cyclic AMP increased the number of follicles/ovary which had three 
layers of granulosa cells, the increase being significant after 5 days of culture. It significantly increased the proportion of such follicles which showed mitotic figures in the granulosa cell layer at 3 days and were therefore still growing at that time, but did not do so at 5 days. It had no effect on the number of follicles with four or more layers of granulosa cells at either time. Since fifty-eight of the total of fifty-nine larger follicles in control ovaries showed mitotic figures, no effect of dcAMP on this parameter could be detected.

The increase in the mean number of larger follicles per ovary which occurred between 3 and 5 days in control (as well as in experimental) ovaries was probably due to gonadotrophin in the calf serum. Recruitment into the category of follicles with three layers must also have taken place, since their numbers were not depleted. The high incidence of mitotic figures in follicles with three layers at 5 days was also probably due to the calf serum. Such growth has not been seen in many series of control ovaries cultured with serum from hypophysectomized sheep.

The stimulation by dcAMP both of $\left[{ }^{3} \mathrm{H}\right]$ thymidine uptake and of follicular growth within the first 3 days of culture suggests that the delayed effect of LH is not mediated through cyclic AMP (unless its production by cultured infantile mouse ovaries in response to $\mathrm{LH}$ is itself delayed, which seems unlikely). The preferential stimulation of growth in small follicles, leading to increased numbers of those with three layers but not of those with four layers of granulosa cells, is unlike the response to FSH, which stimulates growth in follicles of all sizes (Ryle, 1972). The follicular growth pattern seen here closely resembles that induced by steroids (Kent, 1973). Yet, although it is well established that cyclic AMP can stimulate steroidogenesis, at least in luteal tissue, the rapid synthesis of oestradiol- $17 \beta$ in infantile mouse ovaries only begins after at least 2 days' incubation in the presence of both FSH and LH (Ryle, Court \& Morris, 1974). Since the medium was changed daily in Exp. 2, it is unlikely that the effect of dcAMP was due to the accumulation of any steroid. Pitot \& Yatvin (1973), however, quote a number of observations indicating that steroids induce (possibly indirectly) the formation of cyclic AMP in the uterus and oviduct and that cyclic AMP can promote certain uterine changes comparable to those due to oestrogen. It is conceivable, therefore, that steroids stimulate ovarian follicular growth through enhanced synthesis of cyclic AMP. Meanwhile, although the stimulatory pathway is obscure, it has been shown that organized growth in differentiated tissue can be induced by dibutyryl cyclic AMP.

This work was supported by the Ford Foundation.

\section{REFERENGES}

Boggis, J. \& Ryle, M. (1972) An in vitro procedure for the quantitative measurement of folliclestimulating hormone activity. F. Endocr. 54, 355.

Ellsworth, L. R. \& ARMSTRong, D. T. (1973) Luteinization of transplanted ovarian follicles in the rat induced by dibutyryl cyclic AMP. Endocrinology, 92, 840.

Fontaine, Y. A., Fontaine-Bertrand, E., Delerue-Labelle, N. \& Salmon, C. (1971) Ovarian adenyl cyclase; stimulation by hypophyseal gonadotrophins studied in the rat. $\mathcal{F}$. Physiol., Paris, $63,49 \mathrm{~A}$. 
KENT, J. (1973) Some effects of steroids on the immature mouse ovary in vitro. F. Reprod. Fert. 34, 297.

Koch, Y., Zor, U., Pomerantz, S., Chobsiang, P. \& Lindner, H. R. (1973) Intrinsic stimulatory action of follicle-stimulating hormone on ovarian adenylate cyclase. F. Endocr. 58, 677.

Mason, N. R., Schaffer, R. J. \& Toomey, R. E. (1973) Stimulation of cyclic AMP accumulation in rat ovaries in vitro. Endocrinology, 93, 34.

Miller, J. B. \& KEYES, P. L. (1972) In vitro stimulation of corpus luteum formation in the rabbit by dibutyryl cyclic AMP (DcAMP). Abstracts 4th Int. Congr. Endocr., Washington D.C., 1972. Excerpta Med. Int. Congr. Ser. No. 256, 26.

Milner, A.J. (1972) Cyclic AMP and the differentiation of adrenal cortical cells grown in tissue culture. F. Endocr. 55, 404.

Piтot, H. G. \& Yatvin, M. B. (1973) Interrelationships of mammalian hormones and enzyme levels in vivo. Physiol. Rev. 53, 228.

RYLE, M. (1971a) The time factor in responses to pituitary gonadotrophins by mouse ovaries in vitro. J. Reprod. Fert. 25, 61 .

RYLE, M. (1971b) The activity of human follicle-stimulating hormone preparations as measured by a response in vitro. F. Endocr. 51, 97.

RYLE, M. (1972) The growth in vitro of mouse ovarian follicles of different sizes in response to purified gonadotrophins. F. Reprod. Fert. 30, 395.

RYLE, M., CourT, J. \& MorRIs, R. (1974) Synergistic action of FSH and LH on oestrogen production by cultured mouse ovaries. F. Endocr. 61, xxiii. 